\title{
Gendered motivations and aspirations of university physics students in Finland
}

\author{
Ramón S. Barthelemy $\oplus^{1}$ and Alexis V. Knaub $\odot^{2}$ \\ ${ }^{1}$ Department of Physics and Astronomy, The University of Utah, Salt Lake City, Utah 84112, USA \\ ${ }^{2}$ American Association of Physics Teachers, College Park, Maryland 20740, USA
}

(Received 17 June 2019; accepted 15 May 2020; published 2 June 2020)

\begin{abstract}
Finland is known worldwide for their strong $\mathrm{K}-12$ education system and robust gender equality across their nation. However, these facts have not translated into strong representation of women in physics degree attainment and the workforce. This study seeks to understand the motivations and consideration to leave of university physics students in Finland, with a specific focus on gender. Undergraduate students' aspiration to attend graduate school and graduate students' aspiration for an academic career were also assessed. This study uses a survey instrument distributed to Finnish physics students at 5 of the 9 nationwide programs. The responses $(N=329)$ indicate that anxiety increases a students' consideration to leave and that women report higher anxiety and lower self-efficacy in their pursuit of a physics degree than men. Women were also more likely to report being extrinsically motivated to pursue physics than men. Positive intrinsic motivation and self-efficacy predicted the aspiration of graduate school for undergraduates, while only gender predicted interest in academic careers by men and nonacademic careers for women.
\end{abstract}

DOI: $10.1103 /$ PhysRevPhysEducRes.16.010133

\section{INTRODUCTION}

Finland, as a country, is internationally renowned for its grade school education and gender parity, ranking 4th in the world for gender equality [1]. In fact, Finland is the only country worldwide where $\mathrm{K}-12$ girls outperform boys in science [2]. These achievements are important to note, as they could be considered evidence that gender is not a factor for Finnish girls and women in science, technology, engineering, and math (STEM). However, in light of this, Finland still does not have equal gender representation in many STEM fields, including physics [3].

With these facts in mind, we studied Finnish university student motivation and persistence in physics to complete the following goals:

1. Characterize Finnish university student motivation and persistence in physics.

2. Determine if any gender differences exist in motivation and persistence.

\section{PHYSICS EDUCATION IN FINLAND}

As with any education system, descriptions can span multiple pages. We focused this section on the relevant aspects of physics education in Finland.

Published by the American Physical Society under the terms of the Creative Commons Attribution 4.0 International license. Further distribution of this work must maintain attribution to the author(s) and the published article's title, journal citation, and DOI.
Throughout their primary and secondary education, Finnish students receive career guidance [4]. The last two years of high school entail students preparing for either universities or vocational institutions; those interested in physics would enroll in the university track [5]. The university track requires students to take a minimum of one 38-h course on physics, but students can enroll in up to six additional 38-h physics courses [5].

\section{A. University matriculation}

Finnish students interested in university take a matriculation exam that consists of a test on the Finnish language and three of the following tests: a subject in the natural sciences, a subject in the humanities, a foreign language, another national language, or math [6]. Students admitted to the university are entitled to complete both a bachelor's and master's degree [7]. Those interested in physics would take the physics test. In the university system, students take an active role in selecting the courses that complete their major [7]. Students can opt to take courses as lectures with exams or take a more self-study approach through going through reading material and taking an exam based on the reading material [7].

\section{B. Gender and physics in Finland}

Although Finland is internationally lauded for its inclusive policies for women, girls and women may not pursue physics [3]. Even when grades are comparable, girls may not be as interested in science or math majors as boys [8]. Studying Finnish female physicists is a challenge because of how few there are and laws that protect the reporting on 
data such as salary, when sample sizes are small [9]. What is known is that women only receive on average between $20 \%-30 \%$ of Ph.D.s in physics in Finland [9]. In the postsecondary levels, there are fewer and fewer female physicists with only a little over $10 \%$ of the Finnish physics departments having female faculty $[9,10]$. In all there are only 10 female physics professors in Finland, which is equal to about $7 \%$ of all faculty [9]. Physics departments in Finland have been indicated to be gendered in ways that may not support female physicists, such as having issues of sexual harassment and physicists feeling expected to minimize any femininity [11]. Female physicists have noted that they face challenges with work-life balance as well experiencing sexual harassment [12]. In our preliminary study of these data, we found that women and men had similar satisfaction with their physics education and were similar in whether they considered leaving the field [13]. One difference was that women in this study were more likely to be interested in a nonacademic career [13].

\section{MOTIVATION, PERSISTENCE, AND SELF-EFFICACY IN STEM}

There are few studies that examine motivation and persistence in the Finnish STEM context but those that do indicate that there are gender differences $[9,11,12$, 14-17]. Research suggests that Finnish high school girls may have different interests in physics than boys, with girls being more interested in scientific connections to people (e.g., how people see different phenomena) than technology (e.g., how a computer works) $[15,16]$. Another study suggests that teaching style does not produce any differences between Finnish high school girls and boys in motivation in physics [17]. These studies can be reflected upon to advise and support gender research in university physics in Finland. The broader literature in STEM education has put a stronger focus on student's own personal beliefs, or self-efficacy, when considering their motivations in science education.

\section{A. Self-efficacy}

A 1997 book by Bandura summarized the theory of selfefficacy as designed by himself and his colleagues over twenty years, following his first 1977 paper on the selfefficacy of behavioral change [18,19]. Self-efficacy is defined through four main sources that build and contribute to an individual's self-efficacy. The first of these concepts, enactive mastery, concerns an individual's own previous positive and productive experiences with a given area. The second construct, vicarious experiences, shows how an individual can build their own self-beliefs by watching another. The third, verbal persuasion, identifies the role of encouragement from others. The fourth construct, physiological state, accounts for the role of emotion in one's self-efficacy.
The framework of self-efficacy has been widely used in science education research and beyond. The importance placed on this framework has drawn from the proven correlation between self-efficacy on the choice of science major and levels of effort put forth to complete related tasks, such as success in a mathematics course [19-22]. Self-efficacy research has been conducted with a range of ages within the literature. This array has varied from studies at the elementary level [23-27], middle, and high school levels [20,28-31], and at the undergraduate college levels [32-37]. Fewer studies have tackled issues that lay outside the $\mathrm{K}-16$ level. Of those that do they mainly focus on issues of career choice and development which are germane to the conversation of women in physics [21,22,37-43]. Within this bulk of literature many of the pieces focus on gender either explicitly or as a main result within their findings [20-22,24,30,33,37,44].

Self-efficacy has been used to postulate that students in science who believe they can succeed will choose science majors and persist within them and onto careers. Selfefficacy has been shown to be a strong predictor of achievement within science $[20,31,32]$ and persistence within the field [33-35]. Some scholars in the field have even suggested that self-efficacy can hold greater weight as a predictor of science success than other factors such as gender or ethnicity $[28,45]$. Even with this viewpoint many studies have emerged looking directly at the intersection of gender and self-efficacy. Gendered accounts of selfefficacy have shown differences in self-beliefs (or rather confidence levels to do science) between males and females about science [30], mathematics [37], and issues regarding one's career [21].

Clearly, self-efficacy is important in pursuit of STEM education. This importance may translate to physics education as well and is an important aspect to diagnose, study, and assess.

\section{THEORETICAL FRAMEWORK}

The theoretical model chosen for this work is subjective task value (STV) and expectations of success, which when combined are known as expectancy value theorem (EVT). Eccles and her colleagues designed a theoretical model to understand achievement-related choices as they studied the "motivational and social factors influencing such long- and short-range achievement goals and behaviors as career aspirations, vocational and avocational choices..." [46]. This model and theory was called expectancy value theory. The theory they created grew out of the literature concerning achievement and attribution $[47,48]$. The model has two main driving factors that affect whether or not a student chooses a task. They are the expectation of success the student has with the chosen task, and the value (i.e., the subjective task value) the student places on the chosen task $[46,49]$. It should be noted that the factor, expectation of success, is very similar to self-efficacy. The model also 
takes into account cultural norms, which represents an important difference from other models such as selfefficacy [50]. For a full treatment of the model please see Eccles [46], this paper will primarily take focus on subjective task value (STV), which is a significant component of her overall model.

How expectation of success and subjective task value affect choices can be both a conscious and subconscious process, and derive from personal preferences that can be partially built into an individual from social norms [50]. These conscious and subconscious choices are the first of four points that Eccles [46] suggests need to be considered before delving into the explicit features of her theoretical model. These four points are attainment value, intrinsic interest, utility value, and cost. These four points map strongly to the motivation questionnaire used in this study, which asked about students' intrinsic motivation (intrinsic interest), extrinsic motivation (attainment value), personal relevance (utility value), and anxiety (cost). The other two motivation factors discussed below, self-efficacy and selfdetermination, are best reflected by expectancy value theory's secondary category of expectation of success.

Essentially, Eccles et al. [46] argue that we are motivated to pursue tasks which are both of interest and use to us. For example, a student may want to pursue a degree in physics because they recognize the career options it could open up for them. Furthermore, they may also want to pursue a degree in physics because it is something in which they find success or just personally enjoy doing. This is a useful framing for this paper which looks to understand how student motivations impact student career goals (to pursue graduate school for undergraduate students, and academic for graduate students) and their consideration to leave their major or program.

\section{A. Subjective task value}

STV as a framework challenges self-efficacy by taking not only issues of previous mastery and encouragement into concern (which inform self-belief), but also the values and beliefs of the participants making the decisions. The framework has been largely confined to the field of psychology and to work conducted by one research group led by Eccles and her associates. Two studies can be readily identified outside of the Eccles group. One focusing on web-based learning with quantitative methods [51], and another focusing on STV in sports using qualitative methods [52]. The use of qualitative methods in the pieces on STV in sports is unique because all of the work produced by Eccles and her colleagues uses quantitative methods.

STV was produced for studying issues of gender and has been used as such. Eccles work primarily has focused on choices of advanced mathematics courses and eventual careers. Only one study identified did not focus on gender as a unit of analysis, and that was the study focusing on web-based learning [51]. The results of Eccles' work has managed to show that men and women do choose careers and courses at different rates, and these differences can be mediated by the values they place on their options [53]. This is in stark contrast to self-efficacy, where values were never considered and factored into the decision-making processes. Eccles has also discussed the source of these values.

The theoretical work by Eccles [50,54] suggests that socialization plays an important role in the value developments of men and women. These results are interesting in that they suggest that the different ways in which girls and boys are treated can result in their later differential choices as men and women. The theoretical work also added another layer of sophistication to Eccles' model and made it more rigorous in its reach in that the model had a better philosophical and sociological underpinning. Proving itself to be a useful tool in uncovering gender differences in value systems makes STV a strong candidate for inclusion in science education research, though this has not yet occurred. It also may be useful to extend the use of the work to more qualitative studies.

\section{METHODOLOGY}

\section{A. Overview}

This study was done using quantitative research methods analyzing data from an online survey. The survey instrument was built using the science motivation questionnaire (SMQ) as well as questions used commonly in work studying persistence [55-57]. Overall, the study looked at (i) student demographics, (ii) motivations, and (iii) persistence of Finnish university physics students. The survey's questions were specifically worded to be in line with the terms and lexicon of the Finnish education system. For example, "physics major" was substituted with "physics studies." The survey was distributed in English, although Finnish physics education primarily happens in Finnish. English is compulsory for all students in Finland and much of physics education research at the undergraduate level is conducted in English. Consequently, the choice was made to conduct the survey in English for ease of the researcher and dissemination.

\section{B. Data collection}

To qualify for participation in this study students had to be pursuing an undergraduate or graduate degree in physics at a Finnish University. The survey was sent to personal contacts in every physics department across Finland to distribute to physics students in their classrooms and department. Personal contacts were primarily department chairs or staff that the lead author was introduced to. In all, 5 out of 9 Finnish institutions offering physics studies participated in the study [14]. 
Student demographics were collected across many dimensions, including gender, race, citizenship, degree level, university location, and more. The students' motivations were measured using the SMQ that has 30 Likert scale questions, ranging from strongly disagree to strongly agree, about aspects of motivation in physics (Table V). Such items included interest in physics, career utility, and concerns. All of the negative questions (i.e., concerns) were reverse coded in order to align with the other SMQ questions during analysis. Lastly, Finnish physics student were asked about their consideration to leave physics, their satisfaction with their physics education, and switching majors if they could go back and make their decision again.

\section{Analysis}

The analysis proceeded in three phases. Phase 1 looked at the demographic, consideration to leave, and motivation responses to report the descriptive statistics. Phase 2 built a motivation model from the literature [55]. Lastly, phase 3 conducted binary logistic regression with the six motivation factors to find odds ratios (OR) for consideration to leave, graduate student career goals, and undergraduate interest in graduate school. Throughout the analysis differences between women and men are also observed.

\section{Limitations}

A major limitation is that the bulk of the respondents attended the University of Jyväskylä (40\%). Our results may be different had more respondents hailed from other institutions. In our future work, we hope to see if there are any major differences among the intuitions. This recruitment bias was most likely due to the first authors' ability to best disseminate the survey at his host University.

Lastly, this survey was distributed via word-of-mouth and snowball sampling. We do not know if particular populations may not have heard about this survey. Obtaining a precise response rate is not possible. We do not know how many potential respondents heard about the survey.

\section{RESULTS}

\section{A. Phase 1: Descriptive statistics}

In all, 329 usable survey responses were collected. The participants in this study were overwhelming Finnish citizens (96\%) and ethnically Finnish (93\%). The majority of participants were male (70\%) with less than one-third being women (29\%) and a few (1\%) reporting an "other" gender. About half the participants were pursuing their bachelor's degree (47\%), with the other students pursuing their master's (34\%) and Ph.D. (19\%). The majority of students identified as physicists $(66 \%)$ with master's and $\mathrm{Ph} . \mathrm{D}$. students being significantly more likely to identify this way $\left[X^{2}(2)=9.008, p=0.011, \phi=0.165\right]$. Onethird $(33 \%)$ of the participants had a parent or close relative
TABLE I. Participant demographics.

\begin{tabular}{|c|c|c|}
\hline & $n$ & $\%$ \\
\hline \multicolumn{3}{|l|}{ Finnish citizen } \\
\hline Yes & 316 & $96 \%$ \\
\hline No & 13 & $4 \%$ \\
\hline \multicolumn{3}{|l|}{ Race } \\
\hline Finnish & 305 & $93 \%$ \\
\hline European $^{*}$ & 17 & $5 \%$ \\
\hline Asian & 1 & $0 \%$ \\
\hline Indian & 1 & $0 \%$ \\
\hline Other & 5 & $2 \%$ \\
\hline \multicolumn{3}{|l|}{ Gender } \\
\hline Man & 230 & $70 \%$ \\
\hline Woman & 94 & $29 \%$ \\
\hline Other & 4 & $1 \%$ \\
\hline Missing & 1 & $0 \%$ \\
\hline \multicolumn{3}{|l|}{ Degree level } \\
\hline Bachelor's & 155 & $47 \%$ \\
\hline Master's & 113 & $34 \%$ \\
\hline Ph.D. & 61 & $19 \%$ \\
\hline \multicolumn{3}{|c|}{ Identify as physicist } \\
\hline Yes & 218 & $66 \%$ \\
\hline No & 110 & $33 \%$ \\
\hline \multicolumn{3}{|l|}{ University } \\
\hline TUT $^{* *}$ & 69 & $21 \%$ \\
\hline U E. Finland & 41 & $12 \%$ \\
\hline U Jyväskylä & 131 & $40 \%$ \\
\hline U Oulu & 17 & $5 \%$ \\
\hline U Turku & 71 & $22 \%$ \\
\hline \multicolumn{3}{|c|}{ Scientist in family } \\
\hline Yes & 110 & $33 \%$ \\
\hline No & 219 & $67 \%$ \\
\hline
\end{tabular}

who was a scientist, with women (44\%) being significantly more likely than men $(29 \%)$ have a scientist in the family $\left[X^{2}(2)=6.435, p=0.040, \phi=0.141\right]$. Their median age was 24.4 years. University of Jyväskylä had the most respondents (40\%) with the rest coming from Tampere University of Technology (21\%), University of Eastern Finland (12\%), University of Oulu (5\%), and University of Turku (22\%). These results are in Table I.

More than one-third of Finnish physics students considered leaving their major (38\%) with fewer students being unsatisfied with their physics education (26\%) and even fewer saying that they choose another field if given the chance again (16\%). There were no gender differences in these outcomes. These results are found in Table II. There was a large dispersion of after degree job interests found in Tables III and IV. When breaking down the career goals into academia and nonacademic for graduate students, a gender difference emerged. Women were significantly more likely to choose a nonacademic route $(59 \%)$ than men $(20 \%)\left[X^{2}(1)=7.838, p=0.005, \phi=0.358\right]$. The individual motivation item responses are shown in Table $\mathrm{V}$ and disaggregated by gender in Table $\mathrm{V}$, sections (a) to (f). 
TABLE II. Persistence.

\begin{tabular}{|c|c|c|c|}
\hline & & $n$ & $\%$ \\
\hline \multicolumn{4}{|l|}{ Considered leaving major } \\
\hline & Yes $($ total $N=329)$ & 124 & $38 \%$ \\
\hline & -Female (total $N=94)$ & 38 & $40.4 \%$ \\
\hline & -Male (total $N=230)$ & 83 & $36.1 \%$ \\
\hline & -Other (total $N=5)$ & 3 & $60 \%$ \\
\hline & No $($ total $N=329)$ & 205 & $62 \%$ \\
\hline & -Female (total $N=94)$ & 56 & $59.6 \%$ \\
\hline & -Male (total $N=230$ ) & 147 & $63.9 \%$ \\
\hline & -Other $($ total $N=5)$ & 2 & $40 \%$ \\
\hline \multicolumn{4}{|l|}{ Satisfied with physics education } \\
\hline & Yes $($ total $N=329)$ & 244 & $74 \%$ \\
\hline & -Female (total $N=94)$ & 66 & $70.2 \%$ \\
\hline & -Male (total $N=230)$ & 175 & $76.1 \%$ \\
\hline & -Other (total $N=5)$ & 3 & $60 \%$ \\
\hline & No $($ total $N=329)$ & 85 & $26 \%$ \\
\hline & -Female (total $N=94)$ & 28 & $29.8 \%$ \\
\hline & -Male (total $N=230)$ & 55 & $23.9 \%$ \\
\hline & -Other (total $N=5$ ) & 2 & $40 \%$ \\
\hline \multicolumn{4}{|l|}{ Would choose physics again } \\
\hline & Yes $($ total $N=329)$ & 276 & $84 \%$ \\
\hline & -Female (total $N=94)$ & 74 & $78.7 \%$ \\
\hline & -Male (total $N=230)$ & 197 & 86.4 \\
\hline & -Other (total $N=5$ ) & 5 & $100 \%$ \\
\hline & No $($ total $N=329)$ & 51 & $16 \%$ \\
\hline & -Female (total $N=94)$ & 20 & $21.3 \%$ \\
\hline & -Male (total $N=230$ ) & 31 & $13.6 \%$ \\
\hline & -Other (total $N=5)$ & 0 & $0 \%$ \\
\hline
\end{tabular}

TABLE III. Bachelor's and master's career goals.

\begin{tabular}{|c|c|c|c|}
\hline & & $n$ & $\%$ \\
\hline \multirow[t]{4}{*}{ Become a teacher (total $N=268$ ) } & & 36 & $13.5 \%$ \\
\hline & -Female (total $N=73$ ) & 15 & $20.5 \%$ \\
\hline & -Male (total $N=191)$ & 20 & $10.5 \%$ \\
\hline & -Other (total $N=4)$ & 1 & $20 \%$ \\
\hline \multirow[t]{4}{*}{ Find a job within physics (total $N=268$ ) } & & 84 & $26 \%$ \\
\hline & -Female (total $N=73$ ) & 25 & $34.2 \%$ \\
\hline & -Male (total $N=191)$ & 59 & $30.9 \%$ \\
\hline & -Other (total $N=4)$ & 0 & $0 \%$ \\
\hline \multirow[t]{4}{*}{ Find a job outside of physics (total $N=268$ ) } & & 23 & $7 \%$ \\
\hline & -Female (total $N=73$ ) & 5 & $6.8 \%$ \\
\hline & -Male (total $N=191)$ & 18 & $9.4 \%$ \\
\hline & -Other (total $N=4)$ & 0 & $0 \%$ \\
\hline \multirow[t]{4}{*}{ Continue to get a Ph.D. (total $N=268$ ) } & & 96 & $29 \%$ \\
\hline & -Female (total $N=73$ ) & 19 & $26.0 \%$ \\
\hline & -Male $($ total $N=191)$ & 74 & $38.7 \%$ \\
\hline & -Other (total $N=4$ ) & 3 & $75 \%$ \\
\hline \multirow[t]{4}{*}{ Other (total $N=268$ ) } & & 29 & $9 \%$ \\
\hline & -Female (total $N=73$ ) & 9 & $12.3 \%$ \\
\hline & -Male $($ total $N=191)$ & 20 & $10.5 \%$ \\
\hline & -Other (total $N=4)$ & 0 & $0 \%$ \\
\hline
\end{tabular}


TABLE IV. Ph.D. career goals.

\begin{tabular}{|c|c|c|c|}
\hline & & $n$ & $\%$ \\
\hline Become a teacher not at university (total $N=61$ ) & & 0 & $0 \%$ \\
\hline \multirow{4}{*}{$\begin{array}{l}\text { Continue in academia with the goal of working } \\
\text { at a university (total } N=61 \text { ) }\end{array}$} & & 36 & $59 \%$ \\
\hline & -Female (total $N=21$ ) & 7 & $33.3 \%$ \\
\hline & -Male (total $N=39$ ) & 28 & $71.8 \%$ \\
\hline & -Other (total $N=1)$ & 1 & $100 \%$ \\
\hline \multirow[t]{4}{*}{ Find a job in field of physics but not in academia (total $N=61$ ) } & & 16 & $26 \%$ \\
\hline & -Female (total $N=21)$ & 9 & $42.9 \%$ \\
\hline & -Male (total $N=39)$ & 7 & $17.9 \%$ \\
\hline & -Other $($ total $N=1)$ & 0 & $0 \%$ \\
\hline \multirow[t]{4}{*}{ Find a job outside of physics but not in academia (total $N=61$ ) } & & 1 & $2 \%$ \\
\hline & -Female (total $N=21$ ) & 1 & $4.8 \%$ \\
\hline & -Male (total $N=39$ ) & 0 & $0 \%$ \\
\hline & -Other (total $N=1)$ & 0 & $0 \%$ \\
\hline \multirow[t]{4}{*}{ Other (total $N=61$ ) } & & 8 & $13 \%$ \\
\hline & -Female (total $N=21$ ) & 4 & $19.0 \%$ \\
\hline & -Male (total $N=39$ ) & 4 & $10.2 \%$ \\
\hline & -Other (total $N=1)$ & 0 & $0 \%$ \\
\hline
\end{tabular}

TABLE V. Motivation questions.

\begin{tabular}{|c|c|c|c|c|c|}
\hline & Never & Rarely & Sometimes & Usually & Always \\
\hline \multicolumn{6}{|l|}{ Intrinsically motivated } \\
\hline I enjoy learning physics & $0 \%$ & $2 \%$ & $12 \%$ & $50 \%$ & $36 \%$ \\
\hline The physics I learn is more important to me than the grade I receive & $1 \%$ & $3 \%$ & $17 \%$ & $40 \%$ & $40 \%$ \\
\hline I find learning physics interesting & $0 \%$ & $2 \%$ & $8 \%$ & $47 \%$ & $43 \%$ \\
\hline I like physics that challenges me & $1 \%$ & $4 \%$ & $24 \%$ & $46 \%$ & $24 \%$ \\
\hline \multicolumn{6}{|l|}{ Extrinsically motivated } \\
\hline I like to do better than the other students on physics tests & $5 \%$ & $18 \%$ & $26 \%$ & $33 \%$ & $17 \%$ \\
\hline Earning a good physics grade is important to me & $3 \%$ & $16 \%$ & $29 \%$ & $33 \%$ & $19 \%$ \\
\hline I think about how learning physics can help me get a job & $2 \%$ & $16 \%$ & $32 \%$ & $35 \%$ & $16 \%$ \\
\hline I think about how physics grades will affect my overall grade point average & $14 \%$ & $31 \%$ & $30 \%$ & $16 \%$ & $9 \%$ \\
\hline $\begin{array}{l}\text { I think about how physics can help my career } \\
\text { Personal relevance }\end{array}$ & $2 \%$ & $11 \%$ & $33 \%$ & $37 \%$ & $16 \%$ \\
\hline The physics I learn relates to my personal goals & $1 \%$ & $6 \%$ & $26 \%$ & $48 \%$ & $19 \%$ \\
\hline I think about how the physics I learn will be helpful to me & $1 \%$ & $10 \%$ & $30 \%$ & $47 \%$ & $12 \%$ \\
\hline I think about how I will use the physics I learn & $1 \%$ & $10 \%$ & $36 \%$ & $41 \%$ & $12 \%$ \\
\hline The physics I learn is relevant to my life & $1 \%$ & $11 \%$ & $35 \%$ & $38 \%$ & $15 \%$ \\
\hline $\begin{array}{l}\text { The physics I learn has practical value to me } \\
\text { Self-determination }\end{array}$ & $2 \%$ & $13 \%$ & $30 \%$ & $43 \%$ & $12 \%$ \\
\hline If I am having trouble in learning the physics I try to figure out why & $2 \%$ & $14 \%$ & $23 \%$ & $43 \%$ & $18 \%$ \\
\hline I put enough effort into the learning of physics & $1 \%$ & $15 \%$ & $29 \%$ & $44 \%$ & $11 \%$ \\
\hline I use strategies that ensure I learn the physics well & $4 \%$ & $25 \%$ & $34 \%$ & $29 \%$ & $7 \%$ \\
\hline It is my fault if I do not understand the physics & $1 \%$ & $6 \%$ & $39 \%$ & $42 \%$ & $12 \%$ \\
\hline I prepare well for the physics tests and labs & $2 \%$ & $11 \%$ & $32 \%$ & $46 \%$ & $9 \%$ \\
\hline \multicolumn{6}{|l|}{ Self-efficacy } \\
\hline I expect to do as well or better than other students in physics & $5 \%$ & $21 \%$ & $26 \%$ & $35 \%$ & $13 \%$ \\
\hline I am confident I will do well on the physics labs and projects & $2 \%$ & $10 \%$ & $31 \%$ & $48 \%$ & $9 \%$ \\
\hline I believe I can master the knowledge and skills in the physics courses & $2 \%$ & $5 \%$ & $22 \%$ & $51 \%$ & $19 \%$ \\
\hline I am confident I will do well on physics tests & $3 \%$ & $20 \%$ & $38 \%$ & $33 \%$ & $6 \%$ \\
\hline $\begin{array}{l}\text { I believe I can earn a grade of " } 5 \text { " in physics courses } \\
\text { Anxiety }\end{array}$ & $8 \%$ & $20 \%$ & $28 \%$ & $25 \%$ & $19 \%$ \\
\hline I am nervous about how I will do on physics tests (r) & $4 \%$ & $22 \%$ & $29 \%$ & $29 \%$ & $15 \%$ \\
\hline
\end{tabular}


TABLE V. (Continued)

\begin{tabular}{|c|c|c|c|c|c|}
\hline & Never & Rarely & Sometimes & Usually & Always \\
\hline I become anxious when it is time to take a physics test (r) & $8 \%$ & $27 \%$ & $28 \%$ & $23 \%$ & $13 \%$ \\
\hline I worry about failing physics tests (r) & $10 \%$ & $34 \%$ & $26 \%$ & $18 \%$ & $11 \%$ \\
\hline I am concerned that the other students are better in physics (r) & $13 \%$ & $34 \%$ & $27 \%$ & $20 \%$ & $6 \%$ \\
\hline I hate taking physics tests $(r)$ & $18 \%$ & $35 \%$ & $28 \%$ & $12 \%$ & $7 \%$ \\
\hline
\end{tabular}

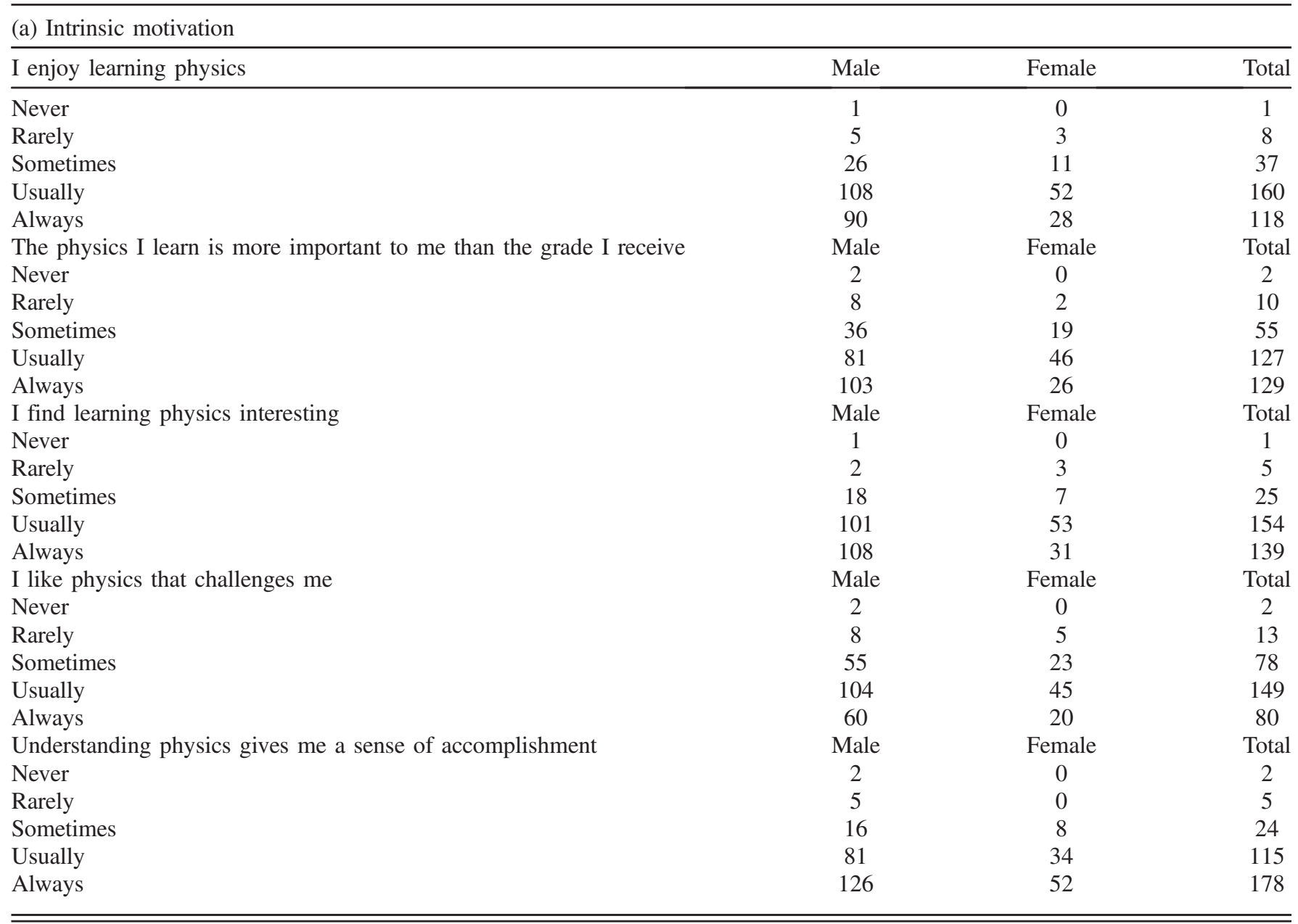

\begin{tabular}{|c|c|c|c|}
\hline I like to do better than the other students on physics tests & Male & Female & Total \\
\hline Never & 12 & 3 & 15 \\
\hline Rarely & 37 & 22 & 59 \\
\hline Sometimes & 60 & 25 & 85 \\
\hline Usually & 79 & 29 & 108 \\
\hline Always & 42 & 14 & 56 \\
\hline Earning a good physics grade is important to me & Male & Female & Total \\
\hline Never & 8 & 2 & 10 \\
\hline Rarely & 40 & 11 & 51 \\
\hline Sometimes & 66 & 29 & 95 \\
\hline Usually & 74 & 33 & 107 \\
\hline Always & 41 & 19 & 60 \\
\hline I think about how learning physics can help me get a job & Male & Female & Total \\
\hline Never & 6 & 0 & 6 \\
\hline Rarely & 40 & 11 & 51 \\
\hline
\end{tabular}


TABLE V. (Continued)

\begin{tabular}{|c|c|c|c|}
\hline I like to do better than the other students on physics tests & Male & Female & Total \\
\hline Sometimes & 72 & 30 & 102 \\
\hline Usually & 80 & 34 & 114 \\
\hline Always & 32 & 19 & 51 \\
\hline I think about how physics grades will affect my overall grade point average & Male & Female & Total \\
\hline Never & 36 & 9 & 45 \\
\hline Rarely & 80 & 20 & 100 \\
\hline Sometimes & 66 & 32 & 98 \\
\hline Usually & 29 & 21 & 50 \\
\hline Always & 17 & 12 & 29 \\
\hline I think about how physics can help my career & Male & Female & Total \\
\hline Never & 5 & 1 & 6 \\
\hline Rarely & 27 & 8 & 35 \\
\hline Sometimes & 76 & 32 & 108 \\
\hline Usually & 88 & 33 & 121 \\
\hline Always & 33 & 20 & 53 \\
\hline
\end{tabular}

(c) Personal relevance

\begin{tabular}{|c|c|c|c|}
\hline The physics I learn relates to my personal goals & Male & Female & Total \\
\hline Never & 2 & 2 & 4 \\
\hline Rarely & 11 & 8 & 19 \\
\hline Sometimes & 57 & 29 & 86 \\
\hline Usually & 111 & 45 & 156 \\
\hline Always & 49 & 10 & 59 \\
\hline I think about how the physics I learn will be helpful to me & Male & Female & Total \\
\hline Never & 2 & 1 & 3 \\
\hline Rarely & 26 & 7 & 33 \\
\hline Sometimes & 71 & 26 & 97 \\
\hline Usually & 103 & 48 & 151 \\
\hline Always & 27 & 12 & 39 \\
\hline I think about how I will use the physics I learn & Male & Female & Total \\
\hline Never & 3 & 1 & 4 \\
\hline Rarely & 23 & 10 & 33 \\
\hline Sometimes & 81 & 32 & 113 \\
\hline Usually & 94 & 39 & 133 \\
\hline Always & 29 & 12 & 41 \\
\hline The physics I learn is relevant to my life & Male & Female & Total \\
\hline Never & 3 & 1 & 4 \\
\hline Rarely & 23 & 13 & 36 \\
\hline Sometimes & 79 & 34 & 113 \\
\hline Usually & 89 & 35 & 124 \\
\hline Always & 36 & 11 & 47 \\
\hline The physics I learn has practical value to me & Male & Female & Total \\
\hline Never & 5 & 0 & 5 \\
\hline Rarely & 29 & 13 & 42 \\
\hline Sometimes & 67 & 32 & 99 \\
\hline Usually & 97 & 42 & 139 \\
\hline Always & 32 & 7 & 39 \\
\hline
\end{tabular}

\begin{tabular}{lcc}
\hline (d) Self-determination & & \\
\hline If I am having trouble in learning the physics I try to figure out why & Male & Female \\
\hline Never & 5 & 3 \\
Rarely & 29 & 8 \\
\hline
\end{tabular}


TABLE V. (Continued)

\begin{tabular}{|c|c|c|c|}
\hline If I am having trouble in learning the physics I try to figure out why & Male & Female & Total \\
\hline Sometimes & 49 & 25 & 74 \\
\hline Usually & 103 & 36 & 139 \\
\hline Always & 44 & 15 & 59 \\
\hline I put enough effort into the learning of physics & Male & Female & Total \\
\hline Never & 2 & 1 & 3 \\
\hline Rarely & 38 & 9 & 47 \\
\hline Sometimes & 61 & 31 & 92 \\
\hline Usually & 101 & 45 & 146 \\
\hline Always & 28 & 8 & 36 \\
\hline I use strategies that ensure I learn the physics well & Male & Female & Total \\
\hline Never & 10 & 4 & 14 \\
\hline Rarely & 61 & 20 & 81 \\
\hline Sometimes & 77 & 33 & 110 \\
\hline Usually & 61 & 33 & 94 \\
\hline Always & 20 & 4 & 24 \\
\hline It is my fault if I do not understand the physics & Male & Female & Total \\
\hline Never & 35 & 5 & 40 \\
\hline Rarely & 104 & 32 & 136 \\
\hline Sometimes & 77 & 47 & 124 \\
\hline Usually & 12 & 8 & 20 \\
\hline Always & 2 & 1 & 3 \\
\hline I prepare well for the physics tests and labs & Male & Female & Total \\
\hline Never & 3 & 2 & 5 \\
\hline Rarely & 31 & 6 & 37 \\
\hline Sometimes & 78 & 25 & 103 \\
\hline Usually & 101 & 46 & 147 \\
\hline Always & 16 & 15 & 31 \\
\hline
\end{tabular}

\section{(e) Self-efficacy}

\begin{tabular}{|c|c|c|c|}
\hline I expect to do as well or better than other students in physics & Male & Female & Total \\
\hline Never & 12 & 4 & 16 \\
\hline Rarely & 46 & 20 & 66 \\
\hline Sometimes & 62 & 21 & 83 \\
\hline Usually & 76 & 37 & 113 \\
\hline Always & 34 & 10 & 44 \\
\hline I am confident I will do well on the physics labs and projects & Male & Female & Total \\
\hline Never & 5 & 2 & 7 \\
\hline Rarely & 18 & 12 & 30 \\
\hline Sometimes & 67 & 35 & 102 \\
\hline Usually & 114 & 41 & 155 \\
\hline Always & 26 & 4 & 30 \\
\hline I believe I can master the knowledge and skills in the physics courses & Male & Female & Total \\
\hline Never & 3 & 2 & 5 \\
\hline Rarely & 10 & 8 & 18 \\
\hline Sometimes & 47 & 23 & 70 \\
\hline Usually & 118 & 47 & 165 \\
\hline Always & 51 & 13 & 64 \\
\hline I am confident I will do well on physics tests & Male & Female & Total \\
\hline Never & 5 & 5 & 10 \\
\hline Rarely & 40 & 25 & 65 \\
\hline Sometimes & 83 & 38 & 121 \\
\hline Usually & 86 & 23 & 109 \\
\hline Always & 16 & 3 & 19 \\
\hline
\end{tabular}


TABLE V. (Continued)

\begin{tabular}{|c|c|c|c|}
\hline I expect to do as well or better than other students in physics & Male & Female & Total \\
\hline I believe I can earn a grade of " 5 " in physics courses & Male & Female & Total \\
\hline Never & 16 & 10 & 26 \\
\hline Rarely & 43 & 22 & 65 \\
\hline Sometimes & 67 & 24 & 91 \\
\hline Usually & 58 & 23 & 81 \\
\hline Always & 46 & 15 & 61 \\
\hline
\end{tabular}

\section{(f) Anxiety}

\begin{tabular}{|c|c|c|c|}
\hline I am nervous about how I will do on physics tests (r) & Male & Female & Total \\
\hline Never & 31 & 18 & \\
\hline Rarely & 62 & 34 & \\
\hline Sometimes & 72 & 24 & \\
\hline Usually & 55 & 15 & \\
\hline Always & 9 & 3 & \\
\hline I become anxious when it is time to take a physics test (r) & Male & Female & Total \\
\hline Never & 23 & 18 & 41 \\
\hline Rarely & 48 & 27 & 75 \\
\hline Sometimes & 67 & 26 & 93 \\
\hline Usually & 69 & 18 & 87 \\
\hline Always & 22 & 5 & 27 \\
\hline I worry about failing physics tests (r) & Male & Female & Total \\
\hline Never & 22 & 14 & 36 \\
\hline Rarely & 36 & 20 & 56 \\
\hline Sometimes & 59 & 28 & 87 \\
\hline Usually & 85 & 25 & 110 \\
\hline Always & 28 & 6 & 34 \\
\hline I am concerned that the other students are better in physics $(r)$ & Male & Female & Total \\
\hline Never & 13 & 6 & 19 \\
\hline Rarely & 42 & 21 & 63 \\
\hline Sometimes & 55 & 33 & 88 \\
\hline Usually & 84 & 27 & 111 \\
\hline Always & 36 & 6 & 42 \\
\hline I hate taking physics tests (r) & Male & Female & Total \\
\hline Never & 15 & 7 & 22 \\
\hline Rarely & 27 & 14 & 41 \\
\hline Sometimes & 63 & 26 & 89 \\
\hline Usually & 80 & 33 & 113 \\
\hline Always & 45 & 14 & 59 \\
\hline
\end{tabular}

(r) Reverse coded.

\section{B. Phase 2}

Using the literature, the 30 motivations questions were broken into six overall factors: intrinsically motivated, extrinsically motivated, personal relevance, selfdetermination, self-efficacy, and anxiety [55]. These factors were created by adding up the responses of five motivation questions that corresponded to each factor resulting in a response scale of 5 to 25 (see Table V). Since each response scale added the factors together for the final number, the minimum for any response was 1 , and the maximum was 5 , thus creating the 5 to 25 scale. Negative items were recoded so that their values are aligned with the other questions. Of the six factors women and men respondents were significantly different on extrinsic motivation $(p=0.042, d=$ $0.251)$, self-efficacy $(p=0.039, d=0.257)$, and anxiety $(p=0.003, d=0.367)$. Men had higher self-efficacy, whereas women had higher anxiety about physics and higher extrinsic motivation. Table VI summarizes these results.

\section{Phase 3}

The six factors were then combined into a complete motivation model with gender and regressed into consideration to leave to understand their impact on this variable. It was found that only one motivation factor impacted 
TABLE VI. Motivation factors by gender.

\begin{tabular}{|c|c|c|c|c|c|c|c|}
\hline & & $N$ & Mean & Std. deviation & $t$ test & Significance $(p)$ & Effect size \\
\hline \multirow[t]{3}{*}{ Intrinsic motivation } & & & & & 1.32 & 0.19 & * \\
\hline & Male & 229 & 21.14 & 2.93 & & & \\
\hline & Female & 92 & 20.67 & 2.67 & & & \\
\hline \multirow[t]{3}{*}{ Extrinsic motivation } & & & & & -2.04 & 0.042 & 0.25 \\
\hline & Male & 227 & 16.4 & 3.48 & & & \\
\hline & Female & 93 & 17.27 & 3.47 & & & \\
\hline \multirow[t]{3}{*}{ Personal relevance } & & & & & 0.844 & 0.4 & $*$ \\
\hline & Male & 229 & 18.03 & 3.47 & & & \\
\hline & Female & 94 & 17.68 & 3.31 & & & \\
\hline \multirow[t]{3}{*}{ Self-determination } & & & & & 0.5 & 0.62 & $*$ \\
\hline & Male & 228 & 17.36 & 2.8 & & & \\
\hline & Female & 93 & 17.18 & 2.9 & & & \\
\hline \multirow[t]{3}{*}{ Self-efficacy } & & & & & 0.91 & 0.039 & 0.26 \\
\hline & Male & 229 & 17.43 & 3.92 & & & \\
\hline & Female & 91 & 16.43 & 3.88 & & & \\
\hline \multirow[t]{3}{*}{ Anxiety (low) } & & & & & 2.96 & 0.003 & 0.37 \\
\hline & Male & 228 & 16.02 & 4.21 & & & \\
\hline & Female & 92 & 14.49 & 4.16 & & & \\
\hline
\end{tabular}

*Not calculated because not statistically significant $(p<0.05)$.

TABLE VII. Motivation impact on consideration to leave.

\begin{tabular}{lcccccc}
\hline \hline & $B$ & S.E. & Wald & $d f$ & Significance & Odds ratio \\
\hline Intrinsic motivation & 0.017 & 0.056 & 0.092 & 1 & 0.761 & 1.017 \\
Extrinsic motivation & 0.046 & 0.045 & 1.046 & 1 & 0.306 & 1.047 \\
Personal relevance & 0.090 & 0.047 & 3.612 & 1 & 0.057 & 1.094 \\
Self-determination & 0.024 & 0.055 & 0.193 & 1 & 0.660 & 1.024 \\
Self-efficacy & -0.10 & 0.045 & 0.046 & 1 & 0.830 & 0.990 \\
Anxiety (low) & 0.114 & 0.036 & 10.010 & 1 & 0.002 & 1.121 \\
Gender & -0.087 & 0.276 & 0.1 & 1 & 0.751 & 0.916 \\
Constant & -4.379 & 1.225 & 11.003 & 1 & 0.001 & 0.017 \\
\hline \hline
\end{tabular}

student consideration to leave-anxiety. Respondents who were less anxious were $12 \%$ more likely than those who were more anxious to not consider leaving their major. Gender was not significant. Table VII summarizes these results.

Lastly, the six motivation factors were combined with gender and regressed into the education and career goals of undergraduate and graduate students, respectively. It was found that for undergraduate students, those with higher intrinsic motivation and self-efficacy were $25 \%$ and $12 \%$ more likely to pursue graduate education, respectively. These results are found in Table VIII. Gender was not a significant factor. For graduate students, this same model was regressed into their interest in pursuing either an

TABLE VIII. Motivation impact on undergraduate student choice of graduate school (career or graduate school).

\begin{tabular}{lcccccc}
\hline \hline & $B$ & S.E. & Wald & $d f$ & Significance & Odds ratio \\
\hline Intrinsic motivation & 0.227 & 0.079 & 8.38 & 1 & 0.004 & 1.26 \\
Extrinsic motivation & 0.005 & 0.054 & 0.007 & 1 & 0.933 & 1.01 \\
Personal relevance & 0.001 & 0.057 & 0.000 & 1 & 0.985 & 1 \\
Self-determination & -0.075 & 0.070 & 1.149 & 1 & 0.284 & 0.928 \\
Self-efficacy & 0.164 & 0.060 & 7.52 & 1 & 0.006 & 1.18 \\
Anxiety (low) & -0.028 & 0.045 & 0.390 & 1 & 0.532 & 0.973 \\
Gender & -0.596 & 0.354 & 2.84 & 1 & 0.092 & 0.551 \\
Constant & -5.78 & 1.69 & 11.7 & 1 & 0.001 & 0.003 \\
\hline \hline
\end{tabular}


TABLE IX. Motivation impact on graduate student career choice (academic or nonacademic).

\begin{tabular}{lrlllcc}
\hline \hline & $B$ & S.E. & Wald & $d f$ & Significance & Odds ratio \\
\hline Intrinsic motivation & -0.126 & 0.182 & 0.478 & 1 & 0.489 & 0.882 \\
Extrinsic motivation & -0.287 & 0.180 & 2.55 & 1 & 0.110 & 0.750 \\
Personal relevance & 0.403 & 0.207 & 3.80 & 1 & 0.051 & 1.496 \\
Self-determination & -0.110 & 0.180 & 0.371 & 1 & 0.542 & 0.896 \\
Self-efficacy & 0.093 & 0.144 & 0.412 & 1 & 0.521 & 1.097 \\
Anxiety (low) & -0.108 & 0.104 & 1.09 & 1 & 0.297 & 0.897 \\
Gender & 2.577 & 0.928 & 7.71 & 1 & 0.005 & 13.155 \\
Constant & 2.397 & 3.282 & 0.533 & 1 & 0.465 & 0.091 \\
\hline \hline
\end{tabular}

academic or nonacademic job. It was found that no motivation factor was significant, but women were over 13 times more likely to aspire to a nonacademic career than men. These results are in Table IX.

\section{DISCUSSION}

Our results suggest that Finnish university physics students experience gender differences in their motivations to pursue physics. Our phase 2 results show that male respondents had higher self-efficacy, a favorable trait, than female respondents. This translates into the expectation of a success motivation factor outlined in EVT. Female respondents had higher anxiety about physics, an undesirable trait, than male respondents, which translates to cost in STV. Our phase 3 results further indicate that this is an issue, as the data suggest that less anxiety is linked to staying in the physics major. Further logistic regressions demonstrated that intrinsic motivation and self-efficacy positively predict undergraduate student goals of going to graduate school. However, only gender could predict graduate students' interest in pursuing academia. Although this was not demonstrated in the consideration to leave data, women's higher anxiety and lower self-efficacy may explain their choice of nonacademic careers. This is consistent with EVT which would argue that women would weigh the higher cost (anxiety) along with their decreased expectation of success (self-efficacy). They may possibly associate their physics education with a potential career in academic physics. Women's stronger extrinsic motivation to pursue physics may also be impacting their choice to pursue nonacademic careers., which translates to the utility value of women in STV to use physics as a career and not an end within itself.

These findings align strongly with STV. These participants, when considering to leave their major, possibly weighed what Eccles [46] would call the "cost" (in our study their anxiety around physics) which then influenced their consideration to leave. In this same vein, the positive motivations of personal interest (intrinsic motivation) and confidence (self-efficacy) could predict undergraduate students' goals of pursuing graduate education in physics. However, STV could not predict graduate students' interest in pursuing either an academic or nonacademic career. For this variable only gender was predicative of the choice. It is not clear why women graduate students are less interested in academic careers, however, this reality is played out in the very low representation of women in Finnish physics faculty positions. More research is needed to understand this trend and recruit more women into the Finnish academic physics system.

\section{CONCLUSION}

Despite all of the positive aspects in Finland for women and for science education, our results suggest that Finnish female university students still face challenges that male students do not face. While this work sheds some light on Finnish physicist experiences, more work is needed. Namely, it would be important to know why these differences exist in the Finnish context considering that some of the issues that exist in other contexts (e.g., the U.S.) do not exist in Finland. As researchers continue to study gender in physics, it is important to consider multiple national contexts and contexts in which fewer issues exist. Only then can we determine whether policies and efforts are truly supporting equity or if there is more to be done.

\section{ACKNOWLEDGMENTS}

The authors would like to thank the Fulbright Finland Foundation for their critical support of R. B., to collect this data in Finland. 
[1] World Economic Forum, Global Gender Gap Report (World Economic Forum, Geneva, 2018), http://www3 .weforum.org/docs/WEF_GGGR_2020.pdf.

[2] OECD, PISA2015: Results in focus (Organisation for Economic Co-operation and Development, Paris, 2015).

[3] G. Stoet and D. C. Geary, The gender-equality paradox in science, technology, engineering, and mathematics education, Psychol. Sci. 29, 581 (2018).

[4] P. Sahlberg, A model lesson: Finland shows us what equal opportunity looks like, Am. Educat. 36, 20 (2012).

[5] Finnish National Board of Education, National core curriculum for general upper secondary schools (Finnish National Board of Education, Helsinki, 2015).

[6] Ministry of Education and Culture, Finnish matriculation examination, 2019. Available from https://minedu.fi/en/ finnish-matriculation-examination.

[7] F. Finland, Higher Education in Finland, 2019. Available from https://www.fulbright.fi/studies-and-research-finland/ higher-education-finland.

[8] A. Chow, J. S. Eccles, and K. Salmela-Aro, Task value profiles across subjects and aspirations to physics and ITrelated sciences in the United States and Finland, Dev. Psychol. 48, 1612 (2012).

[9] K. Miikkulainen, J. Ott, and J. Vapaavuori, Update on Women in Physics in Finland (AIP, New York, 2019).

[10] S. Fyysikkoseura, What you should know about women and physics-Gender equality at the Department of Physics, 2008.

[11] K. Rolin and J. Vainio, Gender in academics in Finland: Tensions between policies and gendering processes in physics departments, Sci. Technol. Studies (2011).

[12] A. Sannino and J. Vainio, Gendered hegemony and its contradictions among Finnish university physicists, Gender Educ. 27, 505 (2015).

[13] A. Knaub and R. Barthelemy, Persistence and career choices of female Finnish university physics students, in Proceedings of the 2018 Physics Education Research Conference, Washington, DC, edited by A. Traxler, Y. Cao, and S. Wolf (AIP, New York, 2018).

[14] K. Banzuki, Women in physics in Finland, AIP Conf. Proc. 102 (2013).

[15] J. Lavonen et al. Students' interest and experiences in physics and chemistry related themes: Reflections based on a ROSE-survey in Finland, Themes Sci. Technol. Educ. 1, 7 (2010).

[16] J. Lavonen et al. Pupil interest in physics: A survey in Finland, Nordic Studies Sci. Educ. 1, 72 (2005).

[17] A. Beerenwinkel and M. Von Arx, Constructivism in practice: An explorator study of teaching patterns and student motivations in physics classrooms in Finland, Germany, and Switzerland, Res. Sci. Educ. 47, 237 (2017).

[18] A. Bandura, Self-efficacy: Toward a unifying theory of behavior change, Psychol. Rev. 84, 191 (1977).

[19] A. Bandura, Self-Efficacy: The Exercise of Control (W.H. Freeman New York, 1997).

[20] S. L. Britner and F. Pajares, Self-efficacy beliefs, motivation, race, and gender in middle school science, J. Women Minorities Sci. Engin. 7, 271 (2001).

[21] A. L. Zeldin, S. L. Britner, and F. Pajares, A comparative study of the self-efficacy beliefs of successful men and women in mathematics, science, and technology careers, J. Res. Sci. Teach. 45, 1036 (2008).

[22] A. L. Zeldin and F. Pajares, Against the odds: Self-efficacy beliefs of women in mathematics, scientific, and technological careers, Am. Educ. Res. J. 37, 215 (2000).

[23] R. Klassen, A cross-cultural investigation of the efficacy beliefs of South Asian immigrant and Anglo nonimmigrant early adolescents, J. Educ. Psychol. 96, 731 (2004).

[24] F. Pajares, M. D. Miller, and M. J. Johnson, Gender Differences in writing self-beliefs of elementary school students, J. Educ. Psychol. 91, 50 (1999).

[25] F. Pajares and G. Valiante, Influences of self-efficacy on elementary students' writing, J. Educ. Res. 90, 353 (1997).

[26] D. F. Shell, C. Colvin, and R. H. Bruning, Self-efficacy, attribution, and outcome expectancy mechanisms in reading and writing achievement: Grade-level and achievementlevel differences, J. Educ. Psychol. 87, 386 (1995).

[27] A. Bandura and D. H. Schunk, Cultivating competence, self-efficacy, and intrinsic interest through proximal self-motivation. J. Personality Social Psychol. 41, 586 (1981).

[28] S. Lau and R. W. Roeser, Cognitive abilities and motivational processes in high school students' situational engagement and achievement in science, Educ. Assessment 8, 139 (2002).

[29] F. G. Lopez and R. W. Lent, Sources of mathematics selfefficacy in high school students, Career Develop. Quarterly 41, 3 (1992).

[30] S. L. Britner and F. Pajares, Sources of science self-efficacy beliefs of middle school students, J. Res. Sci. Teach. 43, 485 (2006).

[31] F. Pajares, S. L. Britner, and G. Valiante, Relation between achievement goals and self-beliefs of middle school students in writing and science, Contemp. Educ. Psychol. 25, 406 (2000).

[32] S. Andrew, Self-efficacy as a predictor of academic performance in science, J. Adv. Nurs. 27, 596 (1998).

[33] L. R. Gwilliam and N.E. Betz, Validity of measures of math- and science-related self-efficacy for African Americans and European Americans, J. Career Assess. 9, 261 (2001).

[34] R. W. Lent, S. D. Brown, and K. C. Larkin, Relation of self-efficacy expectations to academic achievement and persistence, J. Counsel. Psychol. 31, 356 (1984).

[35] D. A. Luzzo, P. Hasper, K. A. Albert, M. A. Bibby, and E. A. Martinelli, Jr., Effects of self-efficacy-enhancing interventions on the mathematics/science self-efficacy and career interests, goals, and actions of career undecided college students, J. Counsel. Psychol. 46, 233 (1999).

[36] T. Matsui, K. Matsui, and R. Ohnishi, Mechanisms underlying math self-efficacy learning of college students, J. Vocat. Behav. 37, 225 (1990).

[37] G. Hackett, Role of mathematics self-efficacy in the choice of math-related majors of college women and men: A path analysis, J. Counsel. Psychol. 32, 47 (1985).

[38] S. L. Anderson and N. E. Betz, Sources of self-efficacy expectations: Their measurement and relation to career development, J. Vocat. Behav. 58, 98 (2001). 
[39] N.Z. Hampton, Sources of academic self-efficacy scale: An assessment tool for rehabilitation counselors, Rehabilitation Counseling Bulletin 41, 260 (1998).

[40] R. S. Barthelemy, M. McCormick, and C. Henderson, Gender discrimination in physics and astronomy: Graduate student experiences of sexism and gender microaggressions, Phys. Rev. Phys. Edu. Res. 12, 020119 (2016).

[41] A. L. Traxler, X. C. Cid, J. Blue, and R. Barthelemy, Enriching gender in PER: A binary past and complex future, Phys. Rev. Phys. Edu. Res. 12, 020114 (2016).

[42] L. J. Sax, K. J. Lehman, R. S. Barthelemy, and G. Lim, Women in physics: a comparison to science, technology, and math education over four decades, Phys. Rev. Phys. Edu. Res. 12, 020108 (2016).

[43] R. Barthelemy, M. McCormick, and C. Henderson, Barriers beyond equity: An exploratory study of women graduate students' career pathways in astronomy, Int. J. Gender, Sci. Technol. 7, 57 (2015).

[44] M. L. Grunert and G. M. Bodner, Finding fulfillment: Women's self-efficacy beliefs and career choices in chemistry, Chem. Educ. Res. Pract. 12, 420 (2011).

[45] H. Kupermintz, Affective and conative factors as aptitude resources in high school science achievement, Educ. Assess. 8, 123 (2002).

[46] J. S. Eccles, Subjective task value, and the Eccles, et al. model of achievement-related choices, in Handbook of Competence and Motivation, edited by A. J. Eliiot and C. S. Dweck (Guilford Press, New York, 2005), p. 105.

[47] V. C. Crandall, Sex differences in expectancy of intellectual and academic reinforcement, in Achievement-Related Behaviors in Children, edited by C. P. Smith (Russell Sage Foundation, New York, 1969), p. 11.
[48] B. Weiner, Human Motivation: Metaphors, Theories, and Research (Sage, Newbury Park, CA, 1992).

[49] J. S. Eccles, Expectancies values and academic behavior, in Achievement and Achievement Motives, edited by J. T. Spence (San Francisco, Freeman, 1983).

[50] J. S. Eccles, Gender roles and women's achievementrelated decisions, Psychol. Women Q. 11, 135 (1987).

[51] C. M. Chiu and E. T. G. Wang, Understanding web-based learning continuance intention: The role of subjective task value, Info. Manage. 45, 194 (2008).

[52] M. Stuart, Sources of subjective task value in sport: An examination of adolescents with high or low value for sport. Appl. Sport Psychol. 15, 239 (2003).

[53] J. S. Eccles, Where are all the women? Gender differences in participation in physical science, and engineering, in Why Aren't More Women in Science?, edited by S. J. Ceci and W. M. Williams (American Psychological Association Washington, DC, 2007), pp. 173-210.

[54] J.S. Eccles, Understanding women's educational and occupational choices, Psychol. Women Q. 18, 585 (1994).

[55] S. M. Glynn and T. R. Koballa, Jr., Motivation to learn science in college, in Handbook of College Science Teaching, edited by J. J. Mintzes and W. H. Leonard (National Science Teachers Association Press, Arlington, VA, 2006), p. 25-32.

[56] N. Ackerman, T. Atherton, A. R. Avalani, C. A. Berven, T. Laskar, A. Neunzert et al., LGBT+ inclusivity in physics and astronomy: A best practices guide, arXiv:1804.08406.

[57] E. Patridge, R. S. Barthelemy, and S. Rankin, Factors impacting the academic climate for LGBQ STEM faculty, J. Women Minorities Sci. Engin. 20, 75 (2014). 